\title{
Fragments as Failed Texts
}

Conceptual Problems in Thomas More's

History of King Richard III and Percy Bysshe Shelley's

A Philosophical View of Reform

Jens Martin Gurr

I have deserted the odorous gardens of literature to journey across the great sandy desert of Politics; not, you may imagine, without the hope of finding some enchanted paradise. In all probability, I shall be overwhelmed by one of the tempestuous columns which are forever traversing with the speed of a storm and the confusion of chaos that pathless wilderness.

(Shelley on A Philosophical View of Reform, November 1819¹)

\section{Introduction: Unintended Fragments}

Had this volume followed the Hollywood logic of "start with an earthquake, then steadily escalate", this contribution would not have survived the editing process: There is no major fire here, no shipwreck, no spectacular bankruptcy, no dramatically failed enterprise; there is not even any material damage. In the context of this volume, the type of failure this essay considers - unintended fragments as 'failed' texts - may seem rather unspectacular. Looking at the reception history and the critical fortunes of the two texts to be discussed here, one might even speak of resounding successes. We will thus also have to address the question of what constitutes 'failure' and who makes the diagnosis - and at what point in time.

1 | Letter to J. \& M. Gisborne, 6 Nov. 1819. 
My two texts, Thomas More's History of King Richard III and Percy Bysshe Shelley's A Philosophical View of Reform, date from the very beginning and the very end of the Early Modern Period in England. More's History, written in the 1510s, but only published posthumously in the 1540 s, despite its fragmentary status quickly came to be celebrated as the founding text of English Humanist historiography. It is concerned with Richard's short reign (1483-1485) and thus with the end of the War of the Roses -1485 and the beginning of the Tudor line probably being the most compelling choice if one wanted to date the beginning of the Early Modern Period in England. Shelley's Philosophical View of Reform, written in $1819 / 1820$, but only published in 1920 , despite its incomplete nature, is frequently hailed as "the most advanced work of political theory of the age". ${ }^{2}$ It outlines Shelley's view of the political situation in England in the post-Napoleonic period and specifically discusses the necessary reforms and possible means of achieving them.

Texts thus abandoned for no obvious external reasons by their authors long before their deaths call for an explanation: I will argue that both of these texts had to remain fragments because of central inconsistencies and conceptual problems, fundamental aporias in the argument, which did not allow for completion and which, it seems, only occurred to the authors in the process of composition and forced them to break off.

These are not, to be sure, the only such texts in the Early Modern Period (or any period ${ }^{3}$ ): In English or German literature, one might equally have discussed Gottfried August Bürger's essay Die Republik England of $1792 / 1793^{4}$ or Wordsworth's The Recluse ${ }^{5}$ as cases in which there are no

2 | Cameron (1974), 149.

3 | A medieval example one might cite here would be Gottfried's Tristan, which breaks off after Tristan's love affair with the second Isolde, Isolde Weißhand. It has been argued that this infidelity of Tristan's was incompatible with the idea of the one fateful love between Tristan and the first Isolde and that this clash between the progression of the narrative as suggested by Gottfried's sources and the ideology and notion of love expounded in his work may have prompted him to break off. For this, cf. the summary discussion of previous assessments in the commentary to the edition of Gottfried von Straßburg (1995), vol. III, 269-274.

4 | For Bürger's “Die Republik England”, cf. Gurr (2007), 239-256 as well as Gassenmeier (1994), 43-79.

5 | For The Recluse as an unintended fragment, cf. Gurr (2003), 153-172. 
authorial comments accounting for the fragmentary status of a text; as a classic case in which an author himself formulates a statement of capitulation or at least utters reservations about his own design, one might refer to Kleist's remarks about his abandoned Guiskard tragedy. ${ }^{6}$

Thus, what I am not concerned with here are texts that have only come down to us as fragments, such as a number of classical Greek tragedies. I also disregard works that remained fragments simply because the author died before completion or for other such obvious external reasons. Finally, I am not concerned with the deliberately fragmentary texts of, say, German Romanticism, hence with the fragment as an aesthetic strategy and poetological concept. $^{7}$

Both my examples are manifestly not cases of 'somehow not quite getting it right' in the sense of Hershel Parker's thoughts on consistency and intended meanings:

Writers repeatedly fail to achieve their intended meanings during the actual creative process, even though their control over the emerging work is then at its strongest. [...] [F]laws which result from shifting or imperfectly realized intentions commonly survive in the printed text in the form of 'contrary details' which we override in our compulsion to make sense of what we read. $(768)^{8}$

Although there seems to be an urge even among theoretically enlightened critics to assume that such things just do not happen to major writers, the cases I am concerned with here are not ones of "contrary details", but rather ones of fundamental problems of consistency. Let us, as it were, attempt to look over the authors' shoulders, tracing the construction and argument of these texts and surgically extracting the central ruptures that may plausibly have led to their status as fragments.

6 | Cf. for instance the rich documentation in the following editions: von Kleist (2000), and von Kleist (2011).

7 | For an excellent comparative discussion of the fragment as an aesthetic strategy in German and English Romanticism, cf. Schmitt (2005).

8 | Parker (1983), 767-774. 


\section{Thomas More's History of King Richard III}

I begin with a reading of Thomas More's History of King Richard III which may be able to contribute to the controversy over why More chose to discontinue work on this text at least 15 years before his death in 1535. Various contemporary sources show that he was simultaneously working on a Latin and an English version around the years 1513-1515. ${ }^{9}$ In this work - essentially the founding text of English Humanist historiography and incidentally Shakespeare's major source for Richard III ${ }^{10}-$, More briefly outlines the background history with the War of the Roses as well as the reign of Edward IV and mainly covers the usurpation of Richard III in 1483 , only proleptically mentioning the battle of Bosworth in 1485 , when the Earl of Richmond defeated him and became King Henry VII, the first Tudor monarch.

Throughout the text, artfully constructed contrasts between key figures, invented highly ornate speeches and clearly moralizing passages of authorial comment and evaluation clearly point to More's didactic intent. 'Truthful' and 'accurate' historiography - problematic as those terms are anyway - is not the purpose here ${ }^{11}$. What is important is the contrast More elaborates between Edward IV and Richard III and the question whether he believes in Richard's death as the end of tyranny and insecurity.

More consistently judges and evaluates the central characters and comments on their actions and moral positions. Thus, in the didactically

9 | For the genesis and editorial history of the work, cf. the standard edition by Sylvester (1963); for a more recent account of the textual history and More's numerous revisions, cf. Hanham (2007).

10 | For a comparative reading of More's and Shakespeare's Richard III, cf. also Gurr (1997), 51-78, where I also discuss in more detail a number of previous attempts to explain the fragmentary status of the History. This section of the present essay is to a considerable extent based on my earlier, more detailed reading of More's History.

11 | Rather, the didactic exaggerations and the recreated, even fictitious speeches etc. are entirely obvious and deliberate characteristics of this form of fictionalized historiography. The genre of humanist historiography does not even claim historical veracity and accuracy in all details in the first place. For the generic conventions, cf. Heinrich (1987). 
styled repertoire of key figures, Richard's predecessor Edward IV is unambiguously heralded as the archetypal Renaissance king:

He was a goodly parsonage, and very Princely to behold, of hearte couragious, politique in counsaile, in aduersitie nothinge abashed, in prosperitie rather ioyfull then prowde, in peace iust and mercifull, in warre, sharpe and fyerce, bolde and hardye, and nathelesse no farther then wysedome woulde, aduenturouse.[...] In whych time of his latter daies, thys Realm was in quyet and prosperous estate: no feare of outewarde enemyes, no warre in hande, nor none towarde, but such as no manne looked for; the people towarde the Prynce, not in a constrayned feare, but in a wyllynge and louynge obedyence: amonge them selfe, the commons in good peace. $(4)^{12}$

The description of Edward as the ideal Christian king endowed with all physical, intellectual and moral qualities becoming the ideal ruler who, in his later years, commanded a peaceful and prosperous realm serves as a foil against which the allegedly tyrannous Richard is all the more decisively contrasted. This explains the obvious exaggerations and stylisations. For just as he sings Edward's praises, he unequivocally maligns Richard and condemns his cruelty: "Now fell ther mischieues thick. And as the thinge euill gotten is neuer well kept: through all the time of his reygne, never ceased there cruel death \& slaughter, till his owne destruccion ended it." (67f.).

More makes very little of the background of the War of the Roses; Richard's murder of King Henry VI is merely given as a rumour; Queen Margaret is not mentioned at all; and the only references to the conflicts between Henry VI and Edward IV are marginal $(6,65)$. The presentation of a moral example far removed from the concrete case at hand is the main concern here. It is sufficient to More's purpose to show a realm in peace and prosperity in which, upon the death of Edward the model king, a cruel tyrant eliminates all opposition, usurps the throne and plunges the realm into disaster. The general impression is that of an episode of anarchy and tyranny under a cruel and corrupt usurper portrayed in the worst possible light; an episode of anarchy and tyranny, however, in an otherwise well-or-

12 | More (1963). All references with page numbers indicated parenthetically in the text will be to this edition. 
dered, even exemplary state, and an episode that ends with " $\mathrm{y}^{\mathrm{e}}$ beste death, and $\mathrm{y}^{\mathrm{e}}$ most righteous" $(82) .{ }^{13}$

Richard is constantly maligned by contrasting him with opponents of morally, intellectually and politically unquestionable stature. Examples might be Queen Elizabeth who, in vigorous, even touching discussions struggles to have her children securely lodged out of Richard's reach, who tries to keep them isolated so he can have them murdered more easily (35f.). Or take Bishop Morton, portrayed as an ideal politician combining political can-do energy and effective diplomatic skills with firm moral principles: "The bishop was a man of gret natural wit, very well lerned, \& honorable in behaueor, lacking no wise waies to win fauor." (90).

Richard's predecessors and opponents are thus all portrayed in the most favourable light, which - together with a number of explicit references to the course of history - affords an understanding of More's view of history. ${ }^{14}$ According to this essentially optimistic, almost, one is tempted to say, eschatological view, the episode of tyranny must end with the usurper's death and the restoration of order. And although the text breaks off before the chronological account has reached the battle of Bosworth and Richard's end, More is unambiguous about Richard's fate, as several anticipatory comments make clear: "King Richarde himselfe as ye shall hereafter here, slain in the fielde, hacked and hewed of his enemies handes, haryed on horsebacke dead, his here in despite torn and togged lyke a cur dogge." (87).

Here, shortly before his account breaks off, More points to the didactic purpose of the History:

13 | Given the number and force of such fairly straightforward judgements, several recent critics overstate their diagnosis of More's history as "a deeply unstable text. There are, for example, frequent narrative disruptions; noticeable inconsistencies in More's descriptions of his characters; a fluctuating attitude toward textual sources; and a chronology that is almost never correct", as Dan Breen approvingly summarizes this line of thought; cf. Breen (2010), 466. Though these features undoubtedly exist, I find somewhat misleading and deconstructively over-ingenious the tradition of reading More's work as an inherently self-deconstructive text foregrounding constant doubts about its own reliability.

14 | For More's view of history, cf. also Heinrich (1987), 17 et passim. 
Which thinges on euery part wel pondered: god neuer gaue this world a more notable example, neither in what vnsuretie standeth this worldly wel, or what mischief worketh the prowde enterprise of a hyghe heart, or finally what wretched end ensueth such dispiteous crueltie. (86)

His work is meant to elaborate three lessons: (1) "in what vnsuretie standeth this worldly wel”, most clearly exemplified in Hastings' sudden downfall; (2) "what mischief worketh the prowde enterprise of a hyghe heart", which is sufficiently illustrated by all the evil committed during Richard's reign; (3) "what wretched end ensueth such dispiteous crueltie", which points to Richard's fate described a few lines later. All three teachings have sufficiently been dealt with up to this point in the History; a continuation of More's account could have added names, dates or events, but could hardly have added anything to his purpose.

While More is thus perfectly explicit about Richard's fate, it is interesting to note that he does not mention Richmond - later Henry VII - as the noble prince rightfully ending Richard's tyrannous reign or refer to him as the military leader who won the decisive battle against Richard at Bosworth; he merely speaks of "his enemies" (87). But given More's opinion about Henry as expressed elsewhere, it is no longer surprising that he should fail to cast him in the role of liberator. For in More's Latin epigrams on the coronation of Henry VIII, the reign of the young king's father Henry VII is described as a period of "slavery" and "sadness", with "laws heretofore powerless - yes, even laws put to unjust ends."

A further revealing view of More's attitude towards Henry VII is afforded by the story of his opposition as a young MP to Henry's demand that parliament grant him $£ 90,000$ for the marriage of his daughter Margaret to James IV of Scotland (1504). More successfully argued against this claim on the grounds that this was an unbearable sum for the citizens to pay. When Henry learned that "a beardless boy" had opposed his plans, he

15 | The Latin Epigrams of Thomas More (1953), 16: "Meta haec seruitii est" (I. 5), "Tristitiae finis" (I. 6), “Leges inualidae prius, imo nocere coactae” (I. 25). Here, More hardly shows consideration or any fear of offending Henry VIII by criticizing his father. In their annotations Bradner and Lynch point out: "The new monarch, however, indicated by his impeachment and execution of his father's principal agents, Empson and Dudley, that he would not resent such comments", Bradner and Lynch, 143. 
is said to have arrested and incarcerated More's father. ${ }^{16}$ The authenticity of this anecdote given by William Roper is not entirely certain, but it is quoted by several scholars without substantial doubt; there appears to be no reason to disbelieve More's son-in-law.

Richmond thus never features as the noble prince who - according to the carefully elaborated didactic structure of the work - would have been needed to end the reign of terror under Richard and to lead the realm back to peace and prosperity. The only reference to Henry VII is ambiguous and most likely ironic: "Howbeit concerning $\mathrm{y}^{\mathrm{t}}$ opinion, with the occasions mouing either partie, we shal haue place more at large to entreate, yf we hereafter happen to write the time of the late noble prince of famous memory king Henry y seuenth." (82f.). In the light of More's view of Henry VII expressed elsewhere, this is almost certainly mere sarcasm. Firstly, the distanced and casual "yf we hereafter happen to write" does sound somewhat facile, suggesting an attitude of 'if, maybe, at some point, I do stoop to write about him'. Secondly, the reference to "the late noble prince" invokes the topos of de mortuis nihil nisi bene; More can thus elegantly imply criticism of Henry without having to elaborate. Thirdly, and most importantly, although it was also already used in its modern sense of 'wellknown', 'famous' in More's days was still closer to its Latin etymology of 'fama' and is therefore recorded to have meant something like 'notorious, ill-famed'. ${ }^{17}$

Viewed together, More's essentially optimistic view of history as expressed in this work, the reference to Richard's end as " $y$ e beste death, and $y^{e}$ most righteous" (82), ending an episode of tyranny, the clearly didactic purpose in contrasting Richard with his allegedly glorious predecessor Edward IV, and finally More's personal opposition to Henry VII and the devastating critique of his reign in the epigrams allow for a plausible hypothesis as to why More may have abandoned the History.

We have seen that his understanding of history as expressed in the History is essentially optimistic: The usurper who unlawfully breaks into an era of peace and prosperity is rightly disposed of. If More had completed his work, an explicit reference to Henry VII as his successor would have been inevitable; but to have the tyrant vanquished and succeeded by a king

16 | For this episode, cf. Roper (1557/1935), 9; quoted in Heinrich's edition (1984), 18ff.

17 | Cf. OED, entry 3 b. 
hardly better than Richard would not have been conducive to More's didactic purpose. A further tyrant would in fact have destroyed the carefully elaborated structure of the work; it would have ruined the didactic conception; it would have created the impression of a fundamentally corrupt state in which one tyrant succeeds another. More has exemplified in Edward IV the connection between the ethos of the king and the well-being of the realm; he has portrayed Richard as the counter-model of a usurper who plunges the state into disaster. More thus exemplifies political positions and different types of politicians. According to this representative structure of the text with Edward IV as the model king and with Richard as the archetypal tyrant ${ }^{18}$, there was simply no room for a further tyrant of Henry's calibre. It seems plausible that the incompatibility of Henry VII with the contrastive approach of his History occurred to More only in the process of writing; the way it was begun, the work could not be finished without great internal incongruities or without blatant falsification of history against the author's commonly known views. This, it seems, accounts better for the fragment status of the History than the explanations previously given. ${ }^{19}$

18 | For a detailed analysis of More's use of individual characters as paradigms of basic political positions, cf. Heinrich (1987), 94ff.

19 | Fox adduces two possible reasons, (1): "It is possible that More failed to complete the History because a more urgent preoccupation intervened, in this case perhaps the need to answer Luther's Contra Henricum in 1522"; (2): "Possibly the judicial murder of the third Duke of Buckingham in 1521 shocked More into recognizing that the history of King Richard III was beginning to be rewritten in his own time [under Henry VIII]" (Fox. Thomas More: History and Providence, 1982, 105, quoted in Heinrich (1987), 16f., cf. also Breen (2010), 467). Both suggestions, however, bring about a need to argue for a time of composition after 1521, which runs counter to an almost unanimous consensus about a terminus ante quem of 1518 (cf. the tradition from More's nephew William Rastell all the way to Sylvester's standard 1963 edition with its persuasive arguments in favour of that dating. Logan has suggested a further reason: "He may also have become convinced that he could never publish the History ... a number of powerful men [or their fathers] had played questionable parts in the events he was recounting." Logan, "Introduction", More (2005), xv-Iviii, xli. Finally, again mainly referring to Fox's work, Breen summarizes as follows a somewhat deconstructive account: "More's History had to end before it was in fact complete because the narrative 
If, from a production perspective, we thus regard the History as a failed text, contemporaneous literary theory raises intriguing questions about auctoritas, authorship and the origins of 'failure' or 'success': On the one hand, Kevin Dunn refers to "authorship" as "an institution that in its fullest form is coterminous with humanism" (9f.) and even argues for humanism as the period "of the fullest exercise of self-authorizing rhetoric in the Western literary tradition before the Romantics". ${ }^{20}$ On the other hand, if, according to the doctrine of inspiration, "God is the source of human creativity [...] [w]ho, then, can claim the rights of authorship over any text?" 21 - and who can be said to 'fail' if an author fails to complete a text? Contemporary notions of auctoritas, it seems, do not permit a discussion of 'failure'. What is more, the reception of More's text made sure such questions did not need to be raised: Within a few decades, it came to be regarded as an exemplary achievement. Roger Ascham's endorsement is illuminating in more than one respect:

Diligence also must be used in [...] describing lively, both the site of places and nature of persons, not only for the outward shape of the body, but also for the inward disposition of the mind, as Thucydides doth in many places very trimly, and Homer every where [...] and our Chaucer doth the same, very praise-worthily. [...] Sir Thomas More, in that pamphlet of Richard the Third, doth in most part, I believe, of all these points so content all men, as if the rest of our story of England were so done, we might well compare with France, or Italy, or Germany, in that behalf. ${ }^{22}$

represents an encroaching realization of the inadequacy of rhetoric as an agent capable of generating a convincing psychological verisimilitude based solely on accounts provided by other historical texts", cf. Breen (2010), 475f.; the reference is to Fox (1989), 125 et passim. This reading, I would argue, entirely overrides the dominant sense of remarkably assured assessments and evaluations and vastly overstates the text's disclaimers and hedging expressions in order to stress its "instability".

20 | Cf. Dunn (1994). For the complex relations between authorship and authority in the period in question, cf. also Miller (1986), esp. 3-8; cf. also Hampton (1990).

21 | Miller (1986), 138. For the issue of human vs. divine creation, cf. Miller (1986), 136-139 as well as Guillory (1983).

22 | Ascham, qtd. in: Höfele (2005), $192 f$. 
Firstly, by placing More's History side by side with Homer, Thucydides and Chaucer, this assessment sheds interesting light on the contemporary understanding of the genre of historiography and its conflation with what we would call 'fiction'. Secondly, More's auctoritas, his “reputation as a scholar, saint and martyr helped [the History] to form the prevailing view of Richard for the following two centuries". ${ }^{23}$ The incomplete status of the history does not appear to have been an issue at all and certainly did not prevent it from quickly becoming the one model to anyone "to be looked for at his hand that would well and advisedly write an history"24 as Ascham further commended it.

\section{Shelley's A Philosophical View of Reform}

My second fragment is Shelley's treatise A Philosophical View of Reform, written in 1819 after the Peterloo Massacre. On 16 August 1819, brutal intervention of the military killed 11 people and wounded about 500 when some 60,000 people assembled in Manchester peacefully to protest in favour of parliamentary reform. Upon hearing of this massacre in his Italian exile, Shelley began his essay, in which, after an overview of the development of liberty in world history since ancient Greece, he discusses the need for political and social reform in Britain, outlines a number of the necessary reforms and attempts to chart a likely path to achieving them. Shelley abandoned the essay at some point early in 1820 and it was only published posthumously as late as $1920 .^{25}$

Desmond King-Hele speaks for many critics of the essay when he calls A Philosophical View of Reform "the last and best of Shelley's political utterances". ${ }^{26}$ Several commentators have even spoken of it as "the most

23 | Hammond (1993), 139.

24 | Ascham, qtd. in Höfele (2005), 191.

25 | Cf. the documentation of composition and publication history in the following edition: Shelley (1965), 3-55. All references with page numbers indicated parenthetically in the text will be to this edition.

26 | King-Hele (1984), 143. Cameron (1973), 10, argues that “[h]is general views on these matters, his social philosophy, received their most complete expression in his long prose work, A Philosophical View of Reform"; Cantor (1997), 22, speaks 
advanced work of political theory of the age". ${ }^{27}$ Nonetheless, it seems that the success of Shelley's essay and the corresponding poems of 1819, which have been influential texts in the history of European socialism, may have made many critics overlook or gloss over the key conceptual problems they pose. ${ }^{28}$ An analysis of the structure of Shelley's argument will show that the text has reached a shattering argumentative impasse at just the point at which it breaks off, a fundamental conceptual problem that is quite sufficient to explain why the text had to remain a fragment.

Let us turn to an overview of the text itself and of the problems it proposes to solve. In the "Introduction", the first of three sections, Shelley gives an overview of the development of liberty in world history from Greece to the England of his own time; in the chapter entitled "On the sentiment of the Necessity of change", he argues the need for change in British society and makes a good number of very reasonable proposals such as enlarging the suffrage, abolishing tithes, parliamentary reform, reducing the national debt, freedom of religion etc. Difficulties only arise in the section entitled "Probable Means", in which Shelley discusses how these reforms are to be achieved. Here, he uneasily hovers between a call for passive resistance and a realization that revolutionary violence may be necessary.

Throughout the essay, there are passages which seem filled with high hopes for imminent change: "The literature of England, an energetic development of which has ever followed or preceded a great and free develop-

of it as the "one text among all of Shelley's writings [...] central to any examination of his political and economic views".

27 | Cameron (1974), 149; Cantor (1997), 42, calls it "the most significant and substantive essay on economic matters produced by any of the English Romantics." Cf. also Hoagwood (1988), 209, and Foot (1984), 180 et passim. Numerous further scholars might be quoted here with similar assessments.

28 I It is plausible, of course, to argue that some of the ambivalence in the Reform essay may be due to Shelley's attempt to harmonize the demands of moderate reformers such as Burdett and Leigh Hunt rallied round Hunt's Examiner with those of the radicals Henry Hunt, Cartwright, Cobbett etc. with Cobbett's Register as their organ. He knew that reform was only possible if reform forces did not neutralize and obstruct each other. But this is hardly enough to account for the key conceptual problems of the treatise. 
ment of the national will, has arisen, as it were, from a new birth." (19). ${ }^{29}$ It is in a similarly optimistic vein that Shelley repeatedly calls for passive resistance in the hope that the tyrants will not be able to uphold for long a system of oppression in the face of a passively resisting multitude prepared to "receive with unshrinking bosoms the bayonets of the charging battalions":

[I]f the tyrants command their troops to fire upon them or cut them down unless they disperse, [the true patriot] will exhort them peaceably to risque the danger, and to expect without resistance the onset of the cavalry, and wait with folded arms the event of the fire of the artillery and receive with unshrinking bosoms the bayonets of the charging battalions. [...] the soldiers are men and Englishmen, and it is not to be believed that they would massacre an unresisting multitude of their countrymen drawn up in unarmed array before them [...] (48f.)

This is the tone and tenor predominant in much of the Reform essay. But despite the high hopes, there are passages in which Shelley comes to realize that peaceful passive resistance may no longer be an option:

It is possible that the period of conciliation is past, and that after having played with the confidence and cheated the expectations of the people, their passions will be too little under discipline to allow them to wait the slow, gradual and certain operation of such a Reform as we can imagine the constituted authorities to concede. (46)

Reform, it seems, may no longer be possible. And after the somewhat stubborn and logically inconsequential assertion that "[i]f the Houses of Parliament obstinately and perpetually refuse to concede any reform to the people, my vote is for universal suffrage and equal representation" (47), Shelley launches into a tortuous line of reasoning that ultimately leads him to the realization that violent "struggle must ensue":

If the Houses of Parliament obstinately and perpetually refuse to concede any reform to the people, my vote is for universal suffrage and equal representation. My

29 | Cf. also the Preface to The Revolt of Islam, where Shelley writes that "[m]ankind appear to me to be emerging from their trance. I am aware, methinks, of a slow, gradual, silent change". Shelley (1970), 34. 
vote is-but, it is asked, how shall this be accomplished [...]? This question I would answer by another. [...] When the majority in any nation arrive at a conviction that it is their duty and their interest to divest the minority of a power employed to their disadvantage; and the minority are sufficiently mistaken as to believe that their superiority is tenable, a struggle must ensue. (47)

While, in a number of passages throughout the essay, he maintains that non-violent protest is the appropriate and promising means to achieve the necessary reforms, he here acknowledges that this is no longer an option under the prevailing political circumstances. The clearest recognition that revolutionary violence is inevitable, however, occurs in the following brief passage: "For so dear is power that the tyrants themselves neither then, nor now, nor ever, left or leave a path to freedom but through their own blood." (6). But even advocacy of revolutionary violence is recognized to be an untenable position. For reforms achieved by means of violence are only attained at the price of their immediate self-cancellation; they cannot be made to last. If the republic Shelley hopes for and is trying to promote is brought about by means of violence, it risks being an unstable one destined for failure: "A Republic, however just in its principle and glorious in its object, would through violence and sudden change which must attend it, incur a great risk of being as rapid in its decline as in its growth." (41).

What lies behind Shelley's hovering between passive resistance and the call for revolution, more precisely, what lies behind his quick insistence that revolution cannot responsibly be claimed as an option, is a profound despair in view of an anthropological scepticism that is uncomfortably hinted at throughout the essay: Shelley apparently came to believe that the masses where neither prepared nor able to carry out a revolution: But there is an even more problematic thought behind it: the masses clearly would not be able even to handle the liberty they might achieve. This is Shelley again, arguing by historical analogy - here with the English Revolution of the mid-17th century and the French Revolution - that a revolution would lead to uncontrollable violence and could not be a means of achieving the desired liberties: "The authors of both [the English and the French] Revolutions proposed a greater and more glorious object than the degraded passions of their countrymen permitted them to attain." (15). Similarly, he argues that "the poor [...] by means of that degraded condition [...] are sufficiently incapable of discerning their own genuine and permanent advantage [...]" (21). This is of course a timeless dilemma: In the context 
of the English Revolution, it occupied and tormented Milton; during the French Revolution, a similar anthropological scepticism prompted Wordsworth and Coleridge to recant their early enthusiasm for the Revolution and made them turn to Burkean conservatism. ${ }^{30}$

It becomes painfully clear in the course of Shelley's treatise that this hovering between a call for passive resistance throughout the better part of the text and the acknowledgement that violence may be inevitable cannot be an ingenious double strategy, superficially claiming to warn the masses against violence while obliquely showing it to be the only solution. Rather, it is the result of a fundamental anthropological and political problem that may well have been impossible to solve under the prevailing conditions: Shelley must have come to understand that neither passive resistance nor violence were possible means of bringing about the desired reforms. $^{31}$

This dilemma of not knowing how to counter oppression, whether by means of passive resistance or by means of revolutionary violence, also occurs in Shelley's poetry written at around the same time. It may, for example, be illustrated by quoting from “The Masque of Anarchy” written at exactly the same time. In a very similar way, Shelley here also hovers between passive resistance and revolutionary violence:

And if then the tyrants dare

Let them ride among you there,

Slash, and stab, and maim, and hew,-

What they like, that let them do.

(II. 340-43, stanza 84)

This closely echoes the call to "receive with unshrinking bosoms the bayonets of the charging battalions" (48) from the Reform treatise; but the acknowledgement we saw in the essay that violent insurrection may be necessary is also present in this versified form of the essay. There is a

30 | For this dilemma, cf. the chapters on Milton and Wordsworth in Gurr (2003).

31 | A letter written nine days before his death in its resigned and defeatist note supports my reading: "England appears to be in a desperate condition [...] I once thought to study these affairs \& write or act in them-I am glad that my good genius said refrain. I see little public virtue, \& I foresee that the contest will be one of blood \& gold [...]", letter to Horace Smith, 29 Jun. 1822; Letters, II, 442. 
strong revolutionary impetus here in the call to cast off the chains of oppression and in the insistence that the tyrants are outnumbered by their hitherto submissive subjects now awakening to their own potential power:

\author{
Rise like Lions after slumber \\ In unvanquishable number- \\ Shake your chains to earth like dew \\ Which in sleep had fallen on you- \\ Ye are many-they are few. \\ (II. 151-55, stanza 38; repeated as the concluding stanza 91, II. 368-72)
}

Arguing that this is "scarcely the best slogan for promoting the stoic virtues of passive resistance", Desmond King-Hele ${ }^{32}$ voices the discomfort many critics have felt about the consistency of these great final lines with the doctrine of passive resistance Shelley expounds elsewhere in the poem. But this mere uneasiness seems to me considerably to underestimate the extent to which the poem in wonderfully persuasive fashion trumpets two entirely irreconcilable ideas at the same time. These lines, having occurred first at a crucial point as stanza 38 of the text, are repeated in a singularly charged context at the very end of the poem - can they be understood as anything but a very clear call for revolutionary violence? Further evidence of Shelley's tendency to advocate violent rebellion is evident in several poems written around 1819. In "An Ode Written October, 1819 ", he speaks of the struggle against oppression as "holy combat" (1. 14); and in the "Song to the Men of England" (1819), he urges: "Forge arms, - in your defence to bear” (1. 24).

Given this ambivalence about possible means of attaining the desired reforms, and given the fact that there is no solution in the essay, let us look at what solutions to the dilemma Shelley offers in the poetry: In "The Masque of Anarchy", despite the contradictory impulses sketched above, the liberation from oppression is brought about by "Hope, that maiden

32 | King-Hele (1984), 148; Cameron (1974), 350, argues about the concluding stanzas of The Masque of Anarchy: "the passage is, in effect, revolutionary without any suggestion of passivity". Cf. also Foot 1984, passim and "Introduction". Foot quite clearly points to the clash between irreconcilable positions in the poem. On the latent contradictions in Shelley's poetry of the same time, cf. also Behrendt (1993), 129f. (on “Song to the Men of England”, 1819). 
most serene" (1.128; stanza 32), who flings herself heroically in front of the apocalyptic riders of oppression, whereupon they die or disappear - hardly a means of reform one would confidently hope for. And in the "Ode to Liberty" of 1820 , who overthrows tyrants all over the world? Well, Liberty, with a capital L, Liberty personified:

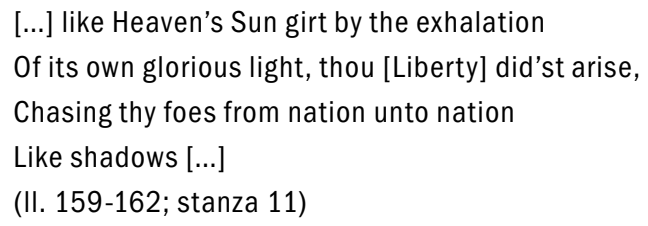

And, again, it is only in poetry that the overthrowing of oppression, the breaking of "Spain's links of steel” can be delegated to "virtue's keenest file": "but Spain's were links of steel,/Till bit to dust by virtue's keenest file" (11. 19of.; stanza 13). And in Prometheus Unbound, it is again an impersonal abstraction, Demogorgon, who overthrows Zeus, the archetypal tyrant.

It is largely through these grand abstractions, I believe, that poems such as "Masque of Anarchy" come across as powerful assertions of political liberty and are still read as great and mature satirical poems and serious contributions to a political debate. This magnificent poetic grandiloquence allows Shelley vaguely to gloss over just that fundamental question of how reform and liberty are to be achieved; the poetic form can sustain such ambiguities; the discursive form of the treatise cannot, even though it is virtually an expository and reasoned version of the contemporaneous poems. Thus, Cantor's assessment of the relationship between the Reform essay and the accompanying poems, persuasive as it may seem, is rather too simple: "Shelley's poetry inspires us to make life better; prose works, like A Philosophical View of Reform, show us how it can actually be done." ${ }^{33}$ Similarly, the reading of the Reform essay in the authoritative 2013 Oxford Handbook of Percy Bysshe Shelley, which summarizes the dominant view, seems entirely to overlook the torturously conflicted, ultimately aporetic nature of Shelley's argumentative endeavour: "The plan of action is prac-

33 | Cantor (1997), 38. Such assumptions of a fairly straightforward and unproblematic relationship between Shelley's poetry and prose of this time are common. For a comparable view of the relationship, cf. Hogle (1988), 223. 
ticable, reasonable, plausible, and unyielding in trying to move society toward radical reform." ${ }^{34}$

Let us turn to the essay again to see how that central aporia forces Shelley to break off at a crucial moment. What Shelley has unwillingly succeeded in making painfully clear in a number of laborious and conflictive argumentative circles in the essay and in the obvious contradictions and evasions in the poetry of the same time is that, first, he sees no hope for gradual and peaceful reform. Secondly, he seems to have come to understand that revolutionary violence is inevitable. But he has made it equally clear that a revolution could only bring about its own decline and could only end in disaster. There is, Shelley has shown at this point in the essay, no solution, for there is no responsible or even feasible means of achieving and securing the desired liberties.

It is virtually on the last page of the essay that this dilemma once more becomes glaringly obvious. This is Shelley again, without any abbreviations or omissions on my part. The hyphen ending in the void and the anguished omission mark of the three dots are all original:

These brief considerations suffice to show that the true friend of mankind and of his country would hesitate before he recommended measures which tend to bring down so heavy a calamity as war-

I imagine however that before the English Nation shall arrive at that point of moral and political degradation now occupied by the Chinese, it will be necessary to appeal to an exertion of physical strength. If the madness of parties admits no other mode of determining the question at issue, ...

When the people shall have obtained, by whatever means, the victory over their oppressors and when persons appointed by them shall have taken their seats in the Representative Assembly of the nation, and assumed control of public affairs according to constitutional rules, there will remain the great task of accommodating all that can be preserved of antient forms with the improvements of the knowledge of a more enlightened age, in legislation, jurisprudence, government and religious and academical institutions. (54; omission marks original $)^{35}$

34 | Scrivener (2013), 172.

35 | David Duff draws attention to this dilemma in Shelley's thought in general and in the Reform treatise in particular: "This, as has often been pointed out, was a dilemma that Shelley never fully resolved. Even in A Philosophical View of Reform 
The solution to Shelley's fundamental question - how to achieve the necessary reforms - remains undiscovered; it lies in the three dots, after which Shelley happily goes to list all the wonderful changes to be made after "the people shall have obtained, by whatever means, the victory over their oppressors" (my italics). Here, in the section "Probable Means", the entire point of which is to delineate ways of achieving "the victory over their oppressors", the evasive "by whatever means" at this crucial moment is the ultimate admission of defeat. Half a page later, after another highly

(1819), his most considered treatment of the topic, he leaves a vacancy - literally a gap in the manuscript - at the crucial point at which he turns to the question of how the people are to obtain 'the victory over their oppressors' which will free them from 'moral and political degradation.'”, Duff (1994), 110. Foot (1984), 189, also remarks upon this gap in Shelley's text. Neither Duff nor Foot, it seems, recognize the centrality of this problem to Shelley's argument, and they certainly do not point it out as a potential reason for the fragmentary nature of the text. Cf. also Foot (1990), 5, where he argues that "the pamphlet is marked throughout with contradictions"; cf. also Cameron (1974), 350. But even Foot glosses over the central aporia in Shelley's argument: "the pamphlet breaks off, leaving two blank pages which Shelley obviously planned to fill in later, perhaps when he had more closely worked out the complex relationship between reform and revolution." Foot further obscures the fundamental problems in the essay when he writes: "The Philosophical View of Reform was ready for its reluctant publisher in 1820", Foot (1990), 7. Cf. also McNiece (1969), 90: "The first problem for Shelley, as for every other reformer, was how to persuade Parliament to reform itself when the membership of the House of Commons was for the most part dedicated to and profiting by the perpetuation of the old order." Interestingly, McNiece closely echoes Shelley's crucial crux apparently without recognizing it as a fundamental problem: "Once the people have won their cause, by whatever means, and have 'assumed the control of public affairs according to constitutional rules [...]'” (92). White similarly fails to see this central problem as a potential reason for Shelley to abandon the work: "In the incomplete nature of Shelley's essay it is impossible to state the steps by which these changes were to be realized.", White (1947), II, 147. White discusses A Philosophical View of Reform on pages 144-151. Dawson (1980), 5 et passim, also comments on this dilemma in Shelley's thoughts and quotes an enlightening passage from Hobsbawm's remarks on millenarian hopes: "millenarian movements share a fundamental vagueness about the actual way in which the new society will be brought about", Hobsbawm (1971), $57 \mathrm{f}$. 
significant reflection on the tendency for bloody revenge in the uneducated masses - another argument against revolution - the essay breaks off.

Rarely has the aporia of an argumentative endeavour stared one in the face more openly. It is hard to see why the landmark 2013 Oxford Handbook of Percy Bysshe Shelley remains so non-committal on this point: "Shelley for unknown reasons never carried the work to completion." (171). There is, it seems, no need to resort to external reasons to explain why the text had to remain incomplete. Fear of not finding a publisher for his essay, as the standard explanation has $\mathrm{it}^{36}$, can hardly have made him give up the project: many of Shelley's texts - including “The Masque of Anarchy” (only published in 1832) - remained unpublished in his lifetime. ${ }^{37}$

Let us finally consider a letter Shelley wrote to John and Maria Gisborne in November 1819 . The letter is usually only cited to date the beginning of Shelley's work on the Reform essay - but it is also an uncomfortable hint at potential problems in the endeavour he was undertaking. Shelley here presciently writes:

I have deserted the odorous gardens of literature to journey across the great sandy desert of Politics; not, you may imagine, without the hope of finding some

36 | Cf. for instance the "Editorial Notes" by Ingpen and Peck, VII, 332. Paul Foot writes about Shelley's failure to complete and to publish the essay and his attempt to get Hunt to publish it or to arrange publication for him: "He knew no one to turn to except Hunt, and Hunt was not amenable. Thus the collection was not published [...]", Foot (1990), 1. Cf. also ibid., 4: "[T]he deafening silence from Hunt [who failed to respond to his requests to arrange for publication of the essay] obliged him to abandon it." Cf. also Foot (1984), passim. In Shelley: The Golden Years, 128, Cameron writes: "Unfortunately, his failure to get a publisher discouraged him from continuing, and the work is unfinished." Some scholars also cite Shelley's letter to Ollier, 15 December 1819; Letters II, 164, in which he states that "now that I see the passion of party will postpone the great struggle till another year, I shall not trouble myself to finish [the Reform treatise] for this season." Cf. for instance Dawson (1980), 197. This is hardly compelling evidence, for as late as May 1820 he was still trying to have it published; cf. the much-quoted letter to Hunt of 26 May 1820, Letters, II, 201.

37 | A Philosophical View of Reform was first published by Oxford University Press in 1920, edited by T.W. Rolleston. For the history of Shelley's manuscript until 1920, cf. for example Peck (1924), 910-918. 
enchanted paradise. In all probability, I shall be overwhelmed by one of the tempestuous columns which are forever traversing with the speed of a storm \& the confusion of chaos that pathless wilderness. ${ }^{38}$

Pathless indeed. Should we not read this as an acknowledgement on Shelley's part that the task he had set himself was an impossible one? For the text in a fascinating way allows one to look over Shelley's shoulder, as it were, and to see him fail - if failure we want to call the sincere struggle to solve a problem that literally was impossible to solve responsibly under the prevailing circumstances. In the contemporary political and economic situation, under the repressive conditions in England in 1819/1820, culminating in the notorious "Six Acts" of December 1819, long before even the moderate reforms of the Reform Bill of 1832 appeared achievable, there could not be a political solution; it was unthinkable. The inability to formulate one was not Shelley's; it was inherent in the structure and the determinants of the political discourse in $1819 / 1820$.

\section{Conclusion: Literary History and the Definition of 'Failure'}

At the very beginning of the Early Modern Period in England, in the 1510s, one of the major writers of the age, Thomas More, is at work on a political biography, an "investigation of the English political system" (Breen 467), a study of political theory. A good 300 years later, in 1819 and thus by any definition at the very end of the Early Modern Period, one of the major writers of the age, Percy Bysshe Shelley, is at work on a synthesis of his political views, an investigation of the English political system, a study of political theory. Although writing under the influence of very different notions of authorship, both writers, it seems, ultimately abandon their texts and leave them fragments because of fundamental conceptual inconsistencies. Both texts remain unpublished during their authors' lifetimes. From the point of view of an aesthetics of production, it is plausible to see both The History of Richard III and A Philosophical View of Reform as cases of failure.

38 | “Letter to John and Maria Gisborne”, November 6 1819, Letters II, 150. 
However, The History of King Richard III, given its undoubted literary merits and the author's auctoritas, his "reputation as a scholar, saint and martyr" 39 , within decades of its composition came to be hailed as the model to anyone "to be looked for at his hand that would well and advisedly write an history"40 and quickly assumed the status of a celebrated text virtually founding the genre of humanist historiography in England. Rather more belatedly, first published exactly a century after its composition, Shelley's Reform essay, in its turn, came to be recognized as "the most advanced work of political theory of the age"41 and is now frequently regarded as "a wonderful inspiration to anyone who feels the same about [contemporary oppressive leaders] as Shelley felt about Lords Liverpool, Castlereagh, Sidmouth and Eldon". ${ }^{2}$ It may be important to note that, while Shelley's essay (as well as early scholarly work by Shelley's then few defenders $)^{43}$ was published at a time when his critical standing was far from secure ${ }^{44}$, broader interest in - and frequently sympathy with - the Reform essay and its clearly progressive politics only arose at a time when Shelley's role as a major Romantic poet and thinker had become virtually unassailable. Shelley's - frequently conservative - detractors, we may note, hardly engaged with the essay; that T.S. Eliot and others would - falsely, as I hope to have shown - have taken Shelley's hovering and evasiveness at key points of the essay as confirming his literary and intellectual immaturity is another matter.

In both More's and Shelley's cases, then, the fragmentary nature of the text hardly plays a role even in the majority of scholarly discussions. Judging by intellectual impact and by later critical as well as popular assessments, one will hardly want to count the History of King Richard III or A Philosophical View of Reform as failures. ${ }^{45}$

39 | Hammond (1993), 139.

40 | Ascham, 5ff., qtd in Höfele (2005), $192 \mathrm{f}$.

41 | Cameron (1974), 149.

42 | Foot (1990). This is Foot's 1990 popular edition of the Reform essay and the accompanying poetry of late 1819 ("Men of England" etc.).

43 | Cf. for instance Peck (1924).

44 | For a history of Shelley's reputation and especially his detractors in the early 20th century, cf. Reiman and Freistat (2002), 539-549.

45 | This essay reuses material from my earlier essays "Two 'Romantic' Fragments" and from “'Bad is the world'”. 


\section{References}

Behrendt, Stephen C. (1993): “The Exoteric Political Poems”, in: Michael O’Neill (ed.), Shelley, London, 122-139.

Breen, Dan (2010): “Thomas More's History of Richard III: Genre, Humanism, and Moral Education”, in: Studies in Philology 107.4, 465-492.

Cameron, Kenneth Neill (1973): “Percy Bysshe Shelley”, in: Kenneth Neill Cameron (ed.), Romantic Rebels: Essays on Shelley and his Circle, Cambridge, Mass., 1-17.

Cameron, Kenneth Neill (1974): Shelley: The Golden Years, Cambridge, Mass.

Cantor, Paul A. (1997): “The Poet as Economist: Shelley's Critique of Paper Money and the British National Debt”, in: Journal of Libertarian Studies 13.1, 21-44.

Dawson, P.M.S. (1980): The Unacknowledged Legislator: Shelley and Politics, Oxford.

Duff, David (1994): Romance and Revolution: Shelley and the Politics of a Genre, Cambridge.

Dunn, Kevin (1994): Pretexts of Authority: The Rhetoric of Authorship in the Renaissance Preface, Stanford.

Foot, Paul (1990): “Introduction”, in: Paul Foot, Shelley's Revolutionary Year: Shelley's Political Poems and the Essay 'A Philosophical View of Reform', ed. Paul Foot, London.

Foot, Paul (1984): Red Shelley, London.

Fox, Alistair (1989): Politics and Literature in the Reigns of Henry VII and Henry VIII. Oxford.

Fox, Alistair (1982): Thomas More: History and Providence, Oxford: Blackwell.

Gassenmeier, Michael (1994): “Gottfried August Bürgers Aufsatz 'Die Republik England”, in: Wolfgang Beutin \& Thomas Bütow (eds), Gottfried August Bürger (1747-1794): Beiträge der Tagung zu seinem 200. Todestag vom 7. bis 9. Juni in Bad Segeberg, Frankfurt a.M., 43-79.

Guillory, John (1983): Poetic Authority: Spenser, Milton, and Literary Histo$r y$, New York.

Gurr, Jens Martin (1997): “'Bad is the world and all will come to nought': History and Morality in More's and Shakespeare's Richard III”, in: Litteraria Pragensia 7, 51-78. 
Gurr, Jens Martin (2003): The Human Soul as Battleground: Variations on Dualism and the Self in English Literature, Heidelberg.

Gurr, Jens Martin (2007): “Two 'Romantic’ Fragments?: Bürger and Shelley on Revolution”, in: Christoph Bode \& Sebastian Domsch (eds.), British and European Romanticisms: Selected Papers from the Munich Conference of the German Society for English Romanticism, Trier, 239256.

Hammond, Peter W. (1993): “The Reputation of Richard III,” in: John Gillingham (ed.), Richard III: A Medieval Kingship, New York, 133-149.

Hampton, Timothy (1990): Writing from History: The Rhetoric of Exemplarity in Renaissance Literature, Ithaca.

Hanham, Alison (2007): “The Texts of Thomas More's Richard III”, in: Renaissance Studies 21.1, 62-84.

Heinrich, Hans-Peter (1987): Sir Thomas Mores 'Geschichte König Richards III' im Lichte humanistischer Historiographie und Geschichtstheorie, Paderborn.

Hoagwood, Terence Allan (1988): Skepticism and Ideology: Shelley's Political Prose and Its Philosophical Contexts from Bacon to Marx, Iowa City.

Hobsbawm, Eric J. (1971): Primitive Rebels: Studies in Archaic Forms of Social Movements in the 19th and 2oth Centuries, Manchester.

Höfele, Andreas (2005): "Making History Memorable: More, Shakespeare and Richard III”, in: Herbert Grabes (ed.), REAL 21: Literature, Literary History, and Cultural Memory, Tübingen, 187-203.

Hogle, Jerrold E. (1988): Shelley's Process: Radical Transference and the Development of His Major Works, New York, Oxford.

King-Hele, Desmond (1984): Shelley: His Thought and Work, London.

Kleist, Heinrich von (2011): Robert Guiskard, Herzog der Normänner, ed. Carlos Spoerhase, Stuttgart.

Kleist, Heinrich von (2000): Robert Guiskard (Sämtliche Werke: Brandenburger Ausgabe, vol. I/2), ed. Roland Reuß and Peter Staengle, Basel,

Logan, George M. (2005): "Introduction”, Thomas More, The History of King Richard III: A Reading Edition, ed. George M. Logan, Bloomington, xv-lviii.

McNiece, Gerald (1969): Shelley and the Revolutionary Idea. Cambridge, Mass.

Miller, Jacqueline T. (1986): Poetic License: Authority and Authorship in Medieval and Renaissance Contexts, Oxford. 
More, Thomas (1963): The History of King Richard III, ed. Richard S. Sylvester (Yale Edition of the Complete Works of St. Thomas More, vol. II). New Haven.

More, Thomas (1953): The Latin Epigrams of Thomas More, ed. Leicester Bradner \& Charles A. Lynch, Chicago.

Parker, Hershel (1983): “Lost Authority: Non-sense, Skewed Meanings, and Intentionless Meanings", in: Critical Inquiry 9.4, 767-774.

Peck, Walter Edwin (1924): "Unpublished Passages from the Pforzheimer MS. of Shelley's Philosophical View of Reform”, in: PMLA 39:1, 910-918.

Reiman, Donald H., and Neil Freistat (2002): “Shelley's Reputation Before 1960: A Sketch”, in: Shelley's Poetry and Prose, ed. Donald H. Reiman and Neil Freistat, New York, 539-549.

Roper, William (1935): The Life of Sir Thomas More, Knight (1557), ed. Elsie Vaughan Hitchcock, London.

Schmitt, Franziska (2005): Method in the Fragments: Fragmentarische Strategien in der englischen und deutschen Romantik (Studien zur Englischen Romantik, Neue Folge, 2), Trier.

Scrivener, Michael (2013): "Politics, Protest, and Social Reform: Irish Pamphlets, Notes to Queen Mab, Letter to Lord Ellenborough, A Philosophical View of Reform", in: Michael O'Neill \& Anthony Howe with the assistance of Madeleine Callaghan (eds.), The Oxford Handbook of Percy Bysshe Shelley, Oxford, 163-176.

Shelley, Percy Bysshe (1965): A Philosophical View of Reform (The Complete Works of Percy Bysshe Shelley, vol. 7), ed. Roger Ingpen and Walter E. Peck, 10 vols., London, 3-55.

Shelley, Percy Pysshe (1970): Poetical Works, ed. Thomas Hutcheson, rev. G.M. Matthews, Oxford.

Shelley, Percy Bysshe (1964): "Letter to John \& Maria Gisborne, 6 Nov. 1819”, in: The Letters of Percy Bysshe Shelley, 2 vols., ed. Frederick L. Jones, Oxford, II, 148-150.

Shelley, Percy Bysshe (1964): “Letter to Ollier, 15 December 1819”, in: The Letters of Percy Bysshe Shelley, 2 vols., ed. Frederick L. Jones, Oxford, II, 164 .

Shelley, Percy Bysshe (1964): “Letter to Leigh Hunt, 26 May 1820”, in: The Letters of Percy Bysshe Shelley, 2 vols., ed. Frederick L. Jones, Oxford, II, 201. 
Shelley, Percy Bysshe (1964): “Letter to Horace Smith, 29 Jun. 1822”, in: The Letters of Percy Bysshe Shelley, 2 vols., ed. Frederick L. Jones, Oxford, II, $44^{2}$.

von Straßburg, Gottfried (1995): Tristan, ed. with a translation into Modern High German and with commentary by Rüdiger Krohn, 3 vols., Stuttgart.

White, Newman Ivey (1947): Shelley, 2 vols., London. 